\title{
Hubungan Kewenangan Pusat dan Daerah dalam Pengawasan Obat di Apotek
}

\author{
Shesha Annisa Desrina \\ Fakultas Hukum Universitas Indonesia \\ Email Korespondensi: shesha_ad@yahoo.com
}

\begin{abstract}
Drugs control in pharmacies is part of concurrent governmental affairs that are divided between the Central Government, the Provincial Region, and the Regency/City Region. The implementation of governance in the regions is carried out with three principles namely decentralization, deconcentration, and co-administration. In the distribution of drug control authority at the pharmacy, there is a conflict between the authority of the Central Government and the Regional Government which has the potential to hamper the effectiveness of drug control. This research raises the issue of the relationship between the authority of the Central Government and Local Governments in drug control in pharmacies and the efforts are made to improve the effectiveness of drug control in pharmacies. The research method used in this study is juridical-normative research through the statutory approach and the conceptual approach. The research results are presented in a prescriptiveanalytical form. The results showed that drug control in pharmacies should be carried out with the principle of deconcentration while giving the authority of BPOM as an institution authorized to conduct drug control in pharmacies. Therefore, Regulation of the Minister of Health Number 73 Year 2016 concerning Pharmaceutical Service Standards in Pharmacy and Minister of Health Regulation Number 9 Year 2017 on Pharmacy needs to be revised by emphasizing that the authority of drug control is the authority of the Central Government, in this case is BPOM. Meanwhile, the Local Government has the authority to supervise the permit for pharmacies and supervise the activities in pharmacies that are not the authority of BPOM.
\end{abstract}

Keywords: Authority; Central Government; Local Government; Drugs Control

\begin{abstract}
ABSTRAK
Pengawasan obat di apotek merupakan bagian dari urusan pemerintahan konkuren yang dibagi antara Pemerintah Pusat, daerah Provinsi, dan daerah Kabupaten/Kota. Penyelenggaraan pemerintahan di daerah dilakukan dengan tiga asas yakni desentralisasi, dekonsentrasi, dan tugas pembantuan. Dalam pembagian kewenangan pengawasan obat di apotek, adanya persinggungan antara kewenangan Pemerintah Pusat dengan Pemerintah Daerah yang berpotensi menghambat efektivitas pengawasan obat. Tulisan ini mengangkat permasalahan hubungan kewenangan Pemerintah Pusat dan Pemerintah Daerah dalam pengawasan obat di apotek dan upaya yang dilakukan untuk meningkatkan efektivitas pengawasan obat di apotek. Metode penelitian yang digunakan dalam penelitian ini adalah penelitian yuridis-normatif melalui pendekatan peraturan perundang-undangan (statute approach) dan pendekatan konseptual (conceptual approach). Hasil penelitian disajikan dalam bentuk preskriptifanalitis. Hasil penelitian menunjukan bahwa pengawasan obat di apotek seharusnya diselenggarakan dengan asas dekonsentrasi dengan tetap menempatkan kewenangan BPOM sebagai lembaga yang berwenang melakukan pengawasan terhadap obat di apotek. Oleh karena itu, Peraturan Menteri Kesehatan Nomor 73 Tahun 2016 tentang Standar Pelayanan Kefarmasian di Apotek dan Peraturan Menteri Kesehatan Nomor 9 Tahun 2017 tentang Apotek perlu direvisi dengan menegaskan bahwa wewenang pengawasan obat merupakan kewenangan Pemerintah Pusat, yakni BPOM. Sedangkan, Pemerintah Daerah berwenang melakukan pengawasan terhadap izin apotek dan penyelenggaraan kegiatan di apotek yang tidak beririsan dengan kewenangan BPOM.
\end{abstract}

Kata Kunci: Kewenangan; Pemerintah Pusat; Pemerintah Daerah; Pengawasan Obat 


\section{Pendahuluan}

Pengawasan obat adalah salah satu kegiatan dalam penyelenggaraan upaya kesehatan. Penyelenggaraan pengawasan obat merupakan tanggung jawab pemerintah dalam mewujudkan derajat kesehatan yang setinggi-tingginya bagi masyarakat. Pengawasan obat, khususnya pada fasilitas pelayanan kefarmasian berupa apotek, perlu didukung dengan regulasi sistem pengawasan yang harmonis, baik dari undang-undang dan peraturan pelaksanaan undang-undang. Regulasi sistem pengawasan seharusnya mengatur secara jelas dan tegas hubungan kewenangan Pemerintah Pusat dan Pemerintah Daerah dalam pelaksanaan pengawasan obat di apotek mengingat bahwa pengawasan obat di apotek merupakan bagian dari urusan pemerintahan konkuren. Penyerahan kewenangan untuk menyelenggarakan fungsi pemerintahan kepada daerah, baik yang berlandaskan pada desentralisasi, dekonsentrasi, maupun tugas pembantuan menuntut pengaturan yang jelas sehingga tidak terjadi tumpang tindih maupun konflik dalam penyelenggaraannya antara tingkatan pemerintahan, baik Pusat, Provinsi, maupun Kabupaten/Kota. Oleh karena itu, sinkronisasi dan sinergi dibutuhkan dalam penyelenggaraan fungsi pemerintahan yang menjadi kewenangan daerah otonom dengan kewenangan Pusat.

Jika merujuk pada rumusan tujuan negara sebagaimana tercantum dalam alinea keempat Pembukaan Undang-Undang Dasar Negara Republik Indonesia Tahun 1945 (UUD NRI Tahun 1945) ${ }^{1}$, menurut Azhary dan Hamid S. Attamimi, Indonesia menganut paham negara kesejahteraan (welfare state). Azhary mengatakan bahwa "negara yang ingin dibentuk (pada waktu itu) oleh bangsa Indonesia ialah negara kesejahteraan dimana kesejahteraan rakyat yang menjadi dasar dan tujuan negara Indonesia merdeka pada ringkasnya keadilan masyarakat atau keadilan sosial.”2 Sedangkan menurut Hamid S. Attamimi,

Negara Indonesia memang sejak didirikan bertekad menetapkan dirinya sebagai negara yang berdasar atas hukum, sebagai rechtstaat. Bahkan rechtstaat Indonesia ialah rechtstaat yang memajukan kesejahteraan umum, mencerdaskan kehidupan bangsa, dan mewujudkan suatu keadilan sosial bagi seluruh rakyat Indonesia. ${ }^{3}$

\footnotetext{
${ }^{1}$ Rumusan tujuan negara yang tercermin dalam alinea ke-empat Pembukaan UUD NRI Tahun 1945 yakni pada kalimat "untuk melindungi segenap bangsa Indonesia dan seluruh tumpah darah Indonesia, dan untuk memajukan kesejahteraan umum, mencerdaskan kehidupan bangsa, dan ikut melaksanakan ketertiban dunia yang berdasarkan kemerdekaan, perdamaian abadi, dan keadilan sosial." Indonesia, Undang-Undang Dasar Negara Republik Indonesia Tahun 1945, Pembukaan.

${ }^{2}$ Azhary, (1995), Negara Hukum Indonesia, Jakarta: UI Press, hlm. 69 dan 116.

${ }^{3}$ Hamid S. Attamimi dalam Ridwan HR, (2011), Hukum Administrasi Negara, Jakarta: Rajawali Pers, hlm. 18.
} 
Salah satu karakteristik konsep negara kesejahteraan adalah kewajiban pemerintah untuk mengupayakan kesejahteraan umum atau bestuurszorg. Menurut E. Utrecht, "adanya bestuurszorg ini menjadi suatu tanda yang menyatakan adanya suatu welfare state."

Dalam bidang kesehatan, sejalan dengan tujuan bernegara tersebut, negara terutama pemerintah memiliki kewajiban untuk menjalankan pembangunan kesehatan serta perlindungan masyarakat dari obat yang berisiko terhadap kesehatan. Dalam rangka memberikan perlindungan tersebut, pemerintah melakukan pengawasan obat dari hulu sampai hilir dengan didukung sistem pengawasan secara komprehensif. Kesehatan itu sendiri pada dasarnya merupakan hak dasar manusia yang dijamin sepenuhnya dalam UUD NRI Tahun 1945 sebagaimana diatur dalam Pasal 28H ayat (1) UUD NRI Tahun $1945 .^{5}$ Sesuai dengan prinsip lainnya dari negara hukum, negara terutama pemerintah, berkewajiban untuk melindungi, memajukan, menegakkan, serta pemenuhan hak asasi manusia dari setiap warga negaranya. Dengan demikian, kewajiban pemerintah dalam pelaksanaan pengawasan obat merupakan wujud untuk mencapai tujuan bernegara dan wujud Indonesia sebagai negara hukum.

Obat sebagai salah satu unsur yang penting dalam upaya kesehatan, mulai dari upaya peningkatan kesehatan, pencegahan, diagnosis, pengobatan dan pemulihan harus diusahakan agar selalu tersedia pada saat dibutuhkan. Obat juga dapat merugikan kesehatan apabila tidak memenuhi persyaratan, digunakan secara tidak tepat atau disalahgunakan. Obat merupakan komponen penting dan strategis dalam pelayanan kesehatan untuk meningkatkan derajat kesehatan masyarakat. Dalam upaya pelayanan kesehatan, ketersediaan obat dalam jenis yang lengkap, jumlah yang cukup, terjamin keamanan, mutu dan manfaatnya dengan harga yang terjangkau serta mudah diperoleh masyarakat adalah sasaran yang harus dicapai oleh pemerintah.

Pada dasarnya dalam penyelenggaraan praktek kefarmasian ${ }^{6}$, tiga unsur yang saling berkaitan satu sama lain adalah produk (sediaan farmasi, termasuk obat), fasilitas

\footnotetext{
${ }^{4}$ E. Utrecht, (1957), Pengantar dalam Hukum Indonesia, Jakarta: Ichtiar, hlm. 30.

${ }^{5}$ Dalam Pasal 28H ayat (1) UUD NRI 1945 disebutkan bahwa "setiap orang berhak hidup sejahtera lahir dan batin, bertempat tinggal, dan mendapatkan lingkungan hidup yang baik dan sehat serta berhak memperoleh pelayanan kesehatan.” Indonesia, Undang-Undang Dasar Negara Republik Indonesia Tahun 1945, Ps. 28 ayat (1).

${ }^{6}$ Indonesia, Undang-Undang Kesehatan, UU No. 36 Tahun 2009, LN No. 144 Tahun 2009, TLN No. 5063, Ps. 108 ayat (1). Dalam Pasal 108 ayat (1) menyebutkan bahwa praktek kefarmasiaan meliputi pembuatan termasuk pengendalian mutu sediaan farmasi, pengamanan, pengadaan, penyimpanan dan pendistribusian obat, pelayanan obat atas resep dokter, pelayanan informasi obat serta pengembangan obat, bahan obat dan obat tradisional harus dilakukan oleh tenaga kesehatan yang mempunyai keahlian dan kewenangan sesuai dengan ketentuan peraturan perundang-undangan. Istilah "praktek kefarmasian” yang diatur dalam Undang-Undang Nomor 36 Tahun 2009 tentang Kesehatan (UU Kesehatan) memiliki definisi yang sama dengan istilah "pekerjaan kefarmasian"
} 
kefarmasian, dan tenaga kefarmasian. Praktek kefarmasian memiliki dimensi yang luas dan kompleks. Pengawasan obat tidak hanya terkait dengan pengawasan produk (sediaan farmasi) tetapi juga terkait dengan pengawasan fasilitas kefarmasian dan pengawasan tenaga kefarmasian. Dalam konteks pengawasan obat di apotek, pengawasan apotek/pengawasan fasilitas kefarmasian tidak dapat dipisahkan dari pengawasan obat. Wewenang pemerintah dalam pelaksanaan pengawasan obat di apotek dilegitimasi dalam beberapa peraturan perundang-undangan antara lain Undang-Undang Nomor 5 Tahun 1997 tentang Psikotropika (UU Psikotropika), Undang-Undang Nomor 35 Tahun 2009 tentang Narkotika (UU Narkotika), Undang-Undang Nomor 36 Tahun 2009 tentang Kesehatan (UU Kesehatan), dan Undang-Undang Nomor 23 Tahun 2014 tentang Pemerintahan Daerah sebagaimana telah beberapa kali diubah terakhir dengan Undang-Undang Nomor 9 Tahun 2015 (UU Pemerintahan Daerah).

Pengawasan sediaan farmasi terdiri dari pengawasan sebelum beredar (pre-market) dan pengawasan selama beredar (post-market). Pengawasan obat di apotek sendiri merupakan bagian dari pengawasan selama beredar (post-market) sediaan farmasi pada sarana pelayanan kefarmasian. Pengawasan obat selama beredar ditujukan untuk memastikan obat yang beredar memenuhi standar dan persyaratan keamanan, khasiat, dan mutu obat yang ditetapkan. Pengertian obat dalam tulisan ini mengacu pada pengertian obat sebagaimana diatur dalam UU Kesehatan. Berdasarkan ketentuan Pasal 1 angka 8 UU Kesehatan adalah bahan atau paduan bahan, termasuk produk biologi yang digunakan untuk mempengaruhi atau menyelidiki sistem fisiologi atau keadaan patologi dalam rangka penetapan diagnosis, pencegahan, penyembuhan, pemulihan, peningkatan kesehatan dan kontrasepsi, untuk manusia. ${ }^{7}$

Dalam konteks pengawasan post-market obat, berdasarkan Peraturan Presiden Nomor 80 Tahun 2017 tentang Badan Pengawas Obat dan Makanan, Badan Pengawas Obat dan Makanan (BPOM) adalah lembaga pemerintah nonkementerian yang menyelenggarakan urusan pemerintahan di bidang pengawasan obat dan makanan. ${ }^{8}$ BPOM mempunyai tugas menyelenggarakan tugas pemerintahan di bidang pengawasan obat dan makanan sesuai

\footnotetext{
sebagaimana diatur dalam Peraturan Pemerintah Nomor 51 Tahun 2009 tentang Pekerjaan Kefarmasian (PP 51 Tahun 2009). Namun, PP 51 Tahun 2009 merupakan peraturan pelaksanaan dari Undang-Undang Nomor 23 Tahun 1992 tentang Kesehatan (UU 23 Tahun 1992), sehingga sesuai dengan ketentuan dalam Pasal 203 UU Kesehatan yang menyebutkan bahwa semua peraturan pelaksanaan UU 23 Tahun 1992 dinyatakan masih tetap berlaku sepanjang tidak bertentangan dengan ketentuan dalam UU Kesehatan, maka istilah yang akan digunakan selanjutnya adalah "praktek kefarmasian."

${ }^{7}$ Indonesia, Undang-Undang Kesehatan, Ps. 1 angka 8.,

${ }^{8}$ Indonesia, Peraturan Presiden tentang Badan Pengawas Obat dan Makanan, Perpres No. 80 Tahun 2017, LN No. 180 Tahun 2017, Ps. 1 ayat (1).
} 
ketentuan peraturan perundang-undangan. ${ }^{9}$ Dalam kerangka pengawasan obat di apotek, BPOM menyelenggarakan fungsi pelaksanaan pengawasan obat selama beredar. ${ }^{10}$

Pengawasan apotek sebagai bagian dari pengawasan fasilitas kefarmasian diatur dalam Peraturan Menteri Kesehatan Nomor 73 Tahun 2016 tentang Standar Pelayanan Kefarmasian di Apotek (Permenkes 73 Tahun 2016) dan Peraturan Menteri Kesehatan Nomor 9 Tahun 2017 tentang Apotek (Permenkes 9 Tahun 2017). Permenkes 73 Tahun 2016 mengatur mengenai pengawasan terhadap standar pelayanan kefarmasian di apotek, sedangkan Permenkes 9 Tahun 2017 mengatur mengenai pengawasan terhadap apotek yang meliputi pengawasan terhadap persyaratan pendirian apotek, perizinan, penyelenggaraan, dan pengalihan tanggung jawab. Hal yang menarik dari kedua Permenkes ini (Permenkes 73 Tahun 2016 dan Permenkes 9 Tahun 2017), ruang lingkup pengawasan apotek diperluas. Ruang lingkup pengawasan meliputi pengawasan pelayanan farmasi klinik dan pengawasan pengelolaan sediaan farmasi. Sehingga, pengawasan apotek meliputi juga didalamnya pengawasan obat. Kewenangan pengawasan apotek dilekatkan kepada Menteri, Kepala Dinas Kesehatan Provinsi, dan Kepala Dinas Kesehatan Kabupaten/Kota. Selain itu, kewenangan pengawasan obat/pengawasan pengelolaan obat di apotek yang diatur dalam kedua Permenkes ini dilekatkan kepada Menteri, Kepala Dinas Kesehatan Provinsi, dan Kepala Dinas Kesehatan Kabupaten/Kota serta secara khusus juga dilekatkan kepada Kepala BPOM. Dengan demikian, kewenangan pengawasan obat di apotek dilekatkan kepada Pemerintah Pusat yakni BPOM dan Pemerintah Daerah, khususnya Pemerintah Daerah Kabupaten/Kota. Hal ini menimbulkan potensi adanya tumpang tindih kewenangan yang dapat berpengaruh terhadap jalannya proses penegakan hukum antara lain tidak adanya kepastian hukum karena Pemerintah Pusat dan Pemerintah Daerah dapat memiliki prosedur penegakan hukum masingmasing serta dapat menerapkan sanksi yang berbeda untuk pelanggaran yang sama.

Penyelenggaraan pengawasan obat di apotek yang dilaksanakan secara desentralisasi melahirkan pola hubungan kewenangan antara Pemerintah Pusat dengan Pemerintah Daerah yang ditandai dengan adanya pembagian wewenang antara Pemerintah Pusat dengan Pemerintah Daerah dalam pengawasan obat di apotek. Hubungan kewenangan ini perlu didukung dengan harmonisasi legislasi dan regulasi peraturan perundang-undangan di bidang pengawasan obat di apotek sehingga tidak menimbulkan upaya tarik menarik kepentingan (spanning of interest) antara Pemerintah Pusat dan Pemerintah Daerah.

\footnotetext{
${ }^{9}$ Ibid., Ps. 2 ayat (1).

${ }^{10}$ Ibid., Ps. 3 ayat (1) huruf d.
} 
Berdasarkan latar belakang di atas, maka permasalahan yang akan dikaji dalam penulisan ini yaitu bagaimana hubungan kewenangan Pusat dan Daerah dalam pengawasan obat di apotek? dan bagaimana upaya meningkatkan efektivitas pengawasan obat di apotek melalui harmonisasi regulasi? Adapun tujuan dari penulisan ini untuk menjelaskan hubungan kewenangan Pusat dan Daerah dalam pengawasan obat di apotek serta upaya meningkatkan efektivitas pengawasan obat di apotek melalui harmonisasi regulasi. Pembahasan dalam tulisan ini dibagi menjadi tiga bagian pembahasan. Pertama, kerangka legal formal wewenang pemerintah dalam pengawasan obat di apotek. Kedua, hubungan kewenangan Pemerintah Pusat dan Pemerintah Daerah dalam pengawasan obat di apotek. Ketiga, serta upaya mewujudkan efektifitas pengawasan obat di apotek. Keseluruhan topik tersebut akan menjadi pedoman alur analisis dalam pembahasan.

\section{Analisis dan Pembahasan}

Obat merupakan bagian integral dari urusan pemerintahan di bidang kesehatan. Ditinjau dari UU Pemerintahan Daerah, urusan pemerintahan di bidang kesehatan adalah salah satu urusan pemerintahan konkuren. Urusan pemerintahan di bidang kesehatan merupakan urusan pemerintahan wajib yang berkaitan dengan pelayanan dasar. Sebagai urusan pemerintahan konkuren, urusan pemerintahan di bidang kesehatan dibagi antara Pemerintah Pusat, Daerah Provinsi, dan Daerah Kabupaten/Kota. Urusan pemerintahan bidang kesehatan terdiri atas empat sub urusan yakni sub urusan: 1) upaya kesehatan; 2) Sumber Daya Manusia (SDM) Kesehatan; 3) Sediaan Farmasi, Alat Kesehatan, dan Makanan Minuman; dan 4) Pemberdayaan Masyarakat Bidang Kesehatan. ${ }^{11}$

Dalam urusan pemerintahan di bidang kesehatan, obat merupakan bagian dari Sub Urusan Sediaan Farmasi, Alat Kesehatan, dan Makanan Minuman. Pola pembagian kewenangan dalam pengawasan obat di apotek antara Pemerintah Pusat dengan Pemerintah Daerah berdasarkan UU Pemerintahan Daerah yakni: (1) Urusan pemerintahan yang menjadi kewenangan Pemerintah Pusat adalah pengawasan post-market obat; dan (2) Urusan pemerintahan yang menjadi kewenangan Pemerintah Daerah Kabupaten/Kota adalah penerbitan izin apotek.

Selain UU Pemerintahan Daerah, pengawasan obat di apotek juga diatur secara rinci dan khusus dalam UU Kesehatan, UU Narkotika, dan UU Psikotropika serta peraturan pelaksanaannya mengenai kewenangan pemerintah dalam pengawasan obat di apotek. Pengaturan dalam UU Pemerintahan Daerah tidak dapat mengenyampingkan pengaturan

\footnotetext{
${ }^{11}$ Indonesia, Undang-Undang tentang Pemerintahan Daerah, UU No. 23 Tahun 2014, LN No. 244 Tahun 2014, TLN No. 5587, Lampiran.
} 
khusus yang diatur dalam UU sektoral tersebut. Dalam ketiga UU sektoral tersebut, hanya UU Kesehatan yang menyebutkan secara eksplisit bahwa Menteri Kesehatan diberikan kewenangan untuk melaksanakan pengawasan obat sebagaimana diatur dalam Pasal 182 ayat (1) yang menyebutkan bahwa "Menteri (Kesehatan) melakukan pengawasan terhadap masyarakat dan setiap penyelenggara kegiatan yang berhubungan dengan sumber daya di bidang kesehatan dan upaya kesehatan." ${ }^{12}$ Kemudian, penjabaran kegiatan pengawasan diatur lebih rinci dalam Pasal 182 sampai dengan Pasal 188 UU Kesehatan. Secara garis besar, kewenangan pengawasan yang diberikan secara atributif kepada Menteri Kesehatan meliputi: (1) Pemberian izin terhadap setiap penyelenggaraan upaya kesehatan; ${ }^{13}$ (2) Mengangkat tenaga pengawas; ${ }^{14}$ (3) Mengambil tindakan administratif terhadap fasilitas pelayanan kesehatan yang melanggar. ${ }^{15}$

Dalam menjalankan kewenangannya, Menteri Kesehatan dapat mendelegasikan kewenangan tersebut kepada lembaga pemerintah nonkementerian, kepala dinas di provinsi, dan kabupaten/kota yang tugas pokok dan fungsinya di bidang kesehatan. ${ }^{16}$ Jika dibandingkan dengan rumusan dalam UU Kesehatan, ketentuan dalam Pasal 61 ayat (1) UU Narkotika ${ }^{17}$ dan Pasal 50 UU Psikotropika ${ }^{18}$ tidak menyebutkan pejabat atau lembaga tertentu yang diberikan kewenangan secara atributif untuk melakukan pengawasan. Hal ini ditandai dengan penggunaan istilah "pemerintah" dan tidak merujuk pada organ pemerintah mana yang diberikan kewenangan pengawasan. Jika dikaitkan dengan urusan pemerintahan yang menjadi kewenangan Pemerintah Pusat dalam UU Pemerintahan Daerah maka Pemerintah Pusat yang

\footnotetext{
${ }^{12}$ Indonesia, Undang-Undang tentang Kesehatan, Ps. 182 ayat (1).

${ }^{13}$ Ibid., Ps. 182 ayat (2). Dalam Pasal 182 ayat (2) disebutkan bahwa Menteri (Kesehatan) dalam melakukan pengawasan sebagaimana dimaksud pada ayat (1) dan ayat (2) dapat memberikan izin terhadap setiap penyelenggaraan upaya kesehatan.

14 Ibid., Ps. 183. Dalam Pasal 183 disebutkan bahwa Menteri (Kesehatan) atau Kepala Dinas dalam melaksanakan tugasnya dapat mengangkat tenaga pengawas dengan tugas pokok untuk melakukan pengawasan terhadap segala sesuatu yang berhubungan dengan sumber daya di bidang kesehatan dan upaya kesehatan.

15 Ibid., Ps. 188 ayat (1). Dalam Pasal 188 ayat (1) disebutkan bahwa Menteri (Kesehatan) dapat mengambil tindakan administratif terhadap tenaga kesehatan dan fasilitas pelayanan kesehatan yang melanggar ketentuan sebagaimana diatur dalam Undang-Undang ini (Kesehatan).

${ }^{16}$ Ibid., Ps. 182 ayat (3) dan Ps. 188 ayat (2). Dalam Pasal 182 ayat (3) disebutkan bahwa Menteri (Kesehatan) dalam melaksanakan pengawasan dapat mendelegasikan kepada lembaga pemerintah nonkementerian, kepala dinas di provinsi, dan kabupaten/kota yang tugas pokok dan fungsinya di bidang kesehatan. Sedangkan dalam Pasal 188 ayat (2) disebutkan bahwa Menteri (Kesehatan) dapat mendelegasikan kewenangan sebagaimana dimaksud pada ayat (1) kepada lembaga pemerintah nonkementerian, kepala dinas provinsi, atau kabupaten/kota yang tugas pokok dan fungsinya di bidang kesehatan.

${ }^{17}$ Indonesia, Undang-Undang tentang Narkotika, UU No. 35 Tahun 2009, LN No. 143 Tahun 2009, TLN No. 5062, Ps. 61 ayat (1). Dalam Pasal 61 ayat (1) UU Narkotika disebutkan bahwa: (1) Pemerintah melakukan pengawasan terhadap segala kegiatan yang berkaitan dengan narkotika.

${ }^{18}$ Indonesia, Undang-Undang tentang Psikotropika, UU No. 5 Tahun 1997, LN No. 10 Tahun 1997, TLN No. 3671, Ps. 50 ayat (1). Dalam Pasal 50 ayat (1) UU Psikotropika disebutkan bahwa: (1) Pemerintah melakukan pengawasan terhadap segala yang berhubungan dengan psikotropika, baik yang dilakukan oleh Pemerintah maupun oleh masyarakat.
} 
berwenang melakukan pengawasan post-market obat merujuk pada BPOM. Hal ini ditegaskan dalam Perpres 80 Tahun 2017 yang merupakan legalitas formal pembentukan Badan Pengawas Obat dan Makanan (BPOM) sebagai lembaga pemerintah nonkementerian yang menyelenggarakan urusan pemerintahan di bidang pengawasan obat dan makanan. Salah satu fungsi BPOM yakni pelaksanaan pengawasan obat selama beredar. ${ }^{19}$

Jika dikaitkan dengan urusan pemerintahan yang menjadi kewenangan Pemerintah Daerah dalam UU Pemerintahan Daerah, kewenangan penerbitan izin apotek dilegitimasi dalam Pasal 12 ayat (2) Permenkes 9 Tahun 2017 yang melimpahkan wewenang pemberian izin apotek dari Menteri Kesehatan kepada Pemerintah Daerah Kabupaten/Kota. ${ }^{20}$ Pada dasarnya, kewenangan penerbitan izin melekat juga kewenangan melakukan pengawasan terhadap segala kegiatan/usaha yang diberikan izin. Kewenangan dalam pengawasan obat di apotek kemudian diatur secara lebih rinci dan khusus dalam beberapa peraturan pelaksanaan ketiga UU sektoral tersebut antara lain Permenkes 73 Tahun 2016 dan Permenkes 9 Tahun 2017.

Dalam Permenkes 73 Tahun 2016, kewenangan pengawasan diatur dalam Pasal 9 dan Pasal 10. Ruang lingkup pengaturan pengawasan dalam Permenkes 73 Tahun 2016 meliputi pengawasan penyelenggaraan pelayanan kefarmasian di apotek. Penyelenggaraan pelayanan kefarmasian di apotek yang diatur dalam Permenkes 73 Tahun 2016 meliputi pengelolaan sediaan farmasi, alat kesehatan, dan bahan medis habis pakai serta pelayanan farmasi klinik yang ditegaskan dalam Pasal 3 ayat (1) Permenkes 73 Tahun 2016. Kewenangan pengawasan diberikan kepada Menteri Kesehatan, Kepala Dinas Kesehatan Provinsi, dan Kepala Dinas Kesehatan Kabupaten/Kota serta memberikan kewenangan khusus kepada Kepala BPOM untuk melakukan pengawasan terhadap pengelolaan sediaan farmasi di apotek. ${ }^{21}$

\footnotetext{
${ }^{19}$ Indonesia, Peraturan Presiden tentang Badan Pengawas Obat dan Makanan, Ps. 3.

${ }^{20}$ Ibid., Ps. 12 ayat (2). Dalam Pasal 12 ayat (2) Permenkes 9 Tahun 2017 menyebutkan bahwa Menteri (Kesehatan) melimpahkan kewenangan pemberian izin (pendirian apotek) kepada Pemerintah Daerah Kabupaten/Kota.

${ }^{21}$ Indonesia, Menteri Kesehatan, Peraturan Menteri Kesehatan tentang Standar Pelayanan Kefarmasian di Apotek, Permenkes No. 73 Tahun 2016, BN No. 50 Tahun 2017, Ps. 3 ayat (1), Ps. 9, dan Ps. 10. Pasal 9 ayat (1) Permenkes No. 73 Tahun 2016 menyebutkan bahwa pembinaan dan pengawasan terhadap pelaksanaan Peraturan Menteri ini dilakukan oleh Menteri, Kepala Dinas Kesehatan Provinsi, dan Kepala Dinas Kesehatan Kabupaten/Kota sesuai dengan tugas dan fungsi masing-masing. Pasal 10 ayat (1) menyebutkan bahwa pengawasan selain dilaksanakan oleh Menteri, Kepala Dinas Kesehatan Provinsi, dan Kepala Dinas Kesehatan Kabupaten/Kota sebagaimana dimaksud dalam Pasal 9 ayat (1), khusus terkait dengan pengawasan sediaan farmasi dalam pengelolaan sediaan farmasi sebagaimana dimaksud dalam Pasal 3 ayat (1) huruf a dilakukan juga oleh Kepala BPOM sesuai dengan tugas dan fungsi masing-masing. Sedangkan dalam Pasal 3 ayat (1) Permenkes 73 Tahun 2016 sendiri menyebutkan bahwa standar pelayanan kefarmasian di apotek meliputi standar: (a) pengelolaan sediaan farmasi, alat kesehatan, dan bahan medis habis pakai; dan (b) pelayanan farmasi klinik.
} 
Dalam Permenkes 9 Tahun 2017, kewenangan pengawasan obat di apotek diatur dalam Pasal 28 dan Pasal 29 Permenkes 9 Tahun 2017. Ruang lingkup pengaturan pengawasan dalam Permenkes 9 Tahun 2017 meliputi pengawasan perizinan dan penyelenggaraan pelayanan kefarmasian di apotek. Pelayanan kefarmasian di apotek yang diatur dalam Permenkes 9 Tahun 2017 meliputi pengelolaan sediaan farmasi, alat kesehatan, dan bahan medis habis pakai serta pelayanan farmasi klinik yang ditegaskan dalam Pasal 16 Permenkes 9 Tahun 2017. ${ }^{22}$ Kewenangan pengawasan diberikan kepada Menteri (Kesehatan), Kepala Dinas Kesehatan Provinsi, dan Kepala Dinas Kesehatan Kabupaten/Kota serta memberikan kewenangan khusus kepada Kepala BPOM untuk melakukan pengawasan terhadap pengelolaan sediaan farmasi di apotek. ${ }^{23}$

Permenkes 73 Tahun 2016 dan Permenkes 9 Tahun 2017 melekatkan kepada Pemerintah Daerah untuk melakukan pengawasan terhadap segala kegiatan/usaha yang diselenggarakan oleh apotek dengan dasar pertimbangan bahwa Pemerintah Daerah telah dilimpahkan wewenang untuk penerbitan izin apotek. Pemerintah Daerah tidak hanya sekedar menerbitkan izin apotek tetapi juga turut bertanggung jawab untuk melakukan pengawasan terhadap segala kegiatan/usaha yang diselenggarakan oleh apotek. Namun dengan luasnya ruang lingkup pengawasan oleh Pemerintah Daerah yang diatur dalam Permenkes 73 Tahun 2016 dan Permenkes 9 Tahun 2017 menyebabkan adanya irisan dalam pelaksanaan kewenangan pengawasan obat di apotek antara BPOM dengan Pemerintah Daerah. Kedua organ pemerintah ini dilekatkan kewenangan pengawasan terhadap pengelolaan obat di apotek. Dengan demikian, keduanya dilekatkan kewenangan untuk melakukan pengawasan terhadap obyek pengawasan yang sama.

\section{Hubungan Kewenangan Pusat dan Daerah dalam Pengawasan Obat di Apotek}

Dalam hukum administrasi negara, hubungan hukum yang terjadi adalah antara penguasa sebagai subyek yang memerintah, dan warga masyarakat sebagai subyek yang diperintah. Penguasa dalam hal ini Pemerintah, melaksanakan bestuurszorg yaitu menyelenggarakan kepentingan umum yang dijalankan oleh penguasa administrasi negara

\footnotetext{
${ }^{22}$ Indonesia, Menteri Kesehatan, Peraturan Menteri Kesehatan tentang Apotek, Permenkes No. 9 Tahun 2017, BN No. 276 Tahun 2017, Ps. 16. Dalam Pasal 16 Permenkes 9 Tahun 2017 disebutkan bahwa apotek menyelenggarakan fungsi: (a) pengelolaan sediaan farmasi, alat kesehatan, dan bahan medis habis pakai; dan (b) pelayanan farmasi klinik, termasuk di komunitas.

${ }^{23}$ Ibid., Ps. 28 ayat (1) dan Ps. 29 ayat (1). Dalam Pasal 28 ayat (1) Permenkes 9 Tahun 2017 menyebutkan bahwa pengawasan terhadap pelaksanaan Peraturan Menteri ini (Permenkes 9 Tahun 2017) dilakukan oleh Menteri, kepala dinas kesehatan provinsi, dan kepala dinas kesehatan kabupaten/kota sesuai dengan tugas dan fungsi masing-masing. Sedangkan Pasal 29 ayat (1) Permenkes 9 Tahun 2017 disebutkan bahwa pengawasan selain dilaksanakan oleh Menteri (Kesehatan), Kepala Dinas Kesehatan Provinsi, dan Kepala Dinas Kesehatan Kabupaten/Kota, khusus terkait dengan pengawasan sediaan farmasi dalam pengelolaan sediaan farmasi dilakukan juga oleh Kepala Badan sesuai dengan tugas dan fungsi masing-masing.
} 
dan pengusa tersebut harus mempunyai wewenang. ${ }^{24}$ Penyelenggaraan pemerintahan harus didasarkan oleh hukum (wetmatigheid van bestuur). Setiap pejabat administrasi negara dalam bertindak (menjalankan tugas-tugasnya) harus dilandasi wewenang yang sah, yang diberikan peraturan perundang-undangan. Dengan wewenang tersebut, seorang aparatur pemerintah dapat membuat suatu kebijakan yang dapat berbentuk suatu keputusan, baik yang bersifat pengaturan (regeling) maupun yang bersifat penetapan (beschiking) ${ }^{25}$

Menurut Prajudi Atmosudirdjo, "salah satu syarat penuaian tugas, fungsi, dan kewajiban yang harus dipenuhi oleh administrasi negara adalah syarat legalitas (wetmatigheid) adalah syarat bagi para pejabat administrasi negara, bahwa segala sesuatunya yang dilakukan atau diputuskan wajib berdasarkan suatu ketentuan undangundang." ${ }^{26}$ Legalitas merupakan syarat, yang menyatakan, bahwa tidak satupun perbuatan atau keputusan administrasi negara yang boleh dilakukan tanpa dasar atau pangkal suatu ketentuan undang-undang (tertulis) dalam arti luas; bila sesuatu dijalankan dengan dalih keadaan darurat, maka kedaruratan tersebut wajib dibuktikan kemudian; bilamana kemudian tidak terbukti, maka perbuatan tersebut dapat digugat di pengadilan. ${ }^{27}$

Asas legalitas dalam bidang hukum administrasi negara merupakan prinsip negara hukum sebagaimana dikemukakan oleh Verhey yang dikutip oleh H.D. Stout yakni:

Asas legalitas dalam bidang hukum administrasi negara merupakan prinsip negara hukum yang dirumuskan dengan ungkapan het beginsel van wetmatigheid van bestuur yakni prinsip keabsahan pemerintah. Prinsip ini mengandung tiga aspek, yakni aspek negatif (het negatieve aspect), aspek formal-positif (het formeel-positieve aspect), dan aspek materiil-positif (het materieel-positieve aspect). Aspek negatif menentukan bahwa tindakan pemerintahan tidak boleh bertentangan dengan undang-undang. Tindakan pemerintahan adalah tidak sah jika bertentangan dengan peraturan perundangundangan yang lebih tinggi. Aspek formal-positif menentukan bahwa pemerintah hanya memiliki kewenangan tertentu sepanjang diberikan atau berdasarkan undang-undang. Aspek materiil-positif menentukan bahwa undang-undang memuat aturan umum yang mengikat tindakan pemerintahan. Hal ini berarti bahwa kewenangan itu harus memiliki dasar peraturan perundang-undangan dan juga kewenangan itu isinya ditentukan normanya oleh undang-undang." 28

Menurut Peter Leyland dan Terry Woods menyatakan bahwa "government acquires its power to act from parliament in statute. The statute legitimises the action (compulsorily

\footnotetext{
${ }^{24}$ Victor Situmorang, (1988), Dasar-Dasar Hukum Administrasi Negara, Jakarta: Bina Aksara, hlm. 18 - 19.

${ }^{25}$ Safri Nugraha, et al, (2005), Hukum Administrasi Negara, cet. 1, Jakarta: Badan Penerbit Fakultas Hukum Universitas Indonesia, hlm. 37.

${ }^{26}$ S. Prajudi Atmosudirdjo, (1994), Hukum Administrasi Negara, cet. 10, Jakarta: Ghalia Indonesia, hlm. 31 32.

${ }^{27}$ Ibid., hlm. 84.

${ }^{28}$ H.D. Stout, De Betekenissen van de Wet, dalam Ridwan HR, (2011), Hukum Administrasi Negara, Jakarta: Rajawali Pers, hlm. $91-92$.
} 
to purchase propety, to allow a refugee into the country, to award and educational grant, etc. It may well lay down the parameters or the power to act, by specifying the power. Jadi, kewenangan pemerintah untuk bertindak diperoleh dari undang-undang yang dibuat oleh parlemen dan melalui undang-undang tersebut, tindakan pemerintah dilegitimasikan. Undang-undang juga meletakkan kewenangan bertindak pemerintah, yang dapat dilakukan dengan menetapkan kriteria-kriteria dari kekuasaan bertindak antar lain tujuan dari tindakan pemerintah, pertimbangan yang harudi diambil dalam melakukan pertanggungjawaban; dan prosedur yang harus dipatuhi sebelum bertindak.

Dengan demikian, sumber wewenang pemerintah terdapat dalam peraturan perundang-undangan. Untuk memperoleh wewenang pemerintah, dapat dilakukan melalui tiga cara sebagai berikut: (a) Atribusi yaitu pemberian wewenang pemerintah yang baru oleh suatu peraturan perundang-undangan (produk hukum legislatif) untuk melaksanakan pemerintahan, secara penuh. Pelekatan secara atribusi merupakan pembentukan kewenangan baru yang sebelumnya tidak ada dan khusus di bidang pemerintahan. Sedangkan "secara penuh" adalah pemberian kewenangan juga termasuk pemberian kewenangan untuk membuat suatu kebijakan yang dapat dituangkan dalam bentuk peraturan perundang-undangan. Dengan kata lain, kebijakan tersebut berada di bawah undang-undang karena dalam rangka pelaksanaan undang-undang ; (b) Delegasi yaitu suatu pelimpahan wewenang yang telah ada yang berasal dari wewenang atribusi, kepada pejabat administrasi negara, tidak secara penuh. Pelimpahan "tidak secara penuh" berarti tidak termasuk wewenang untuk pembentukan kebijakan karena wewenang pembentukan kebijakan tersebut berada di tangan pejabat yang mendapat pelekatan secara atribusi; (c) Mandat yaitu pemberian tugas dari mandans (pemberi mandat) kepada mandataris (penerima mandat) untuk aas nama pemberi mandat membuat keputusan administrasi negara. Pada mandat, wewenang tetap berada di tangan mandans, sedangkan mandataris hanya melaksanakan perintah secara atas nama saja dan tanggung jawab tetap di tangan mandans. ${ }^{30}$

Ditinjau dari sumber perolehan wewenang, wewenang pengawasan obat di apotek, baik pengawasan terhadap penyelenggaraan apotek dan perizinan apotek, secara atributif diberikan kepada Menteri Kesehatan. Hal ini ditegaskan dalam Pasal 182 ayat (1) dan ayat (2) UU Kesehatan. Menteri Kesehatan juga diberikan wewenang untuk dapat mendelegasikan wewenang tersebut kepada lembaga pemerintah nonkementerian, kepala

\footnotetext{
${ }^{29}$ Peter Leyland and Terry Woods, (1999), Administrative Law, London: Blackstone Press Limited, hlm. 142.

${ }^{30}$ Safri Nugraha, Hukum Administrasi Negara, hlm. 41 - 42.
} 
dinas di provinsi, dan kabupaten/kota yang tugas pokok dan fungsinya di bidang kesehatan. Namun, tidak satupun peraturan pelaksanaan UU Kesehatan yang menyatakan secara eksplisit bahwa pengawasan dilimpahkan atau didelegasikan kepada lembaga pemerintah nonkementerian, kepala dinas di provinsi, dan kabupaten/kota yang tugas pokok dan fungsinya di bidang kesehatan. Sehingga, pada dasarnya kewenangan dalam pengawasan obat di apotek merupakan kewenangan Pemerintah Pusat.

Dalam negara kesatuan yang didesentralisasikan, kewenangan yang dijalankan oleh Pemerintah Pusat dalam negara kesatuan sangatlah luas. Sehingga mutlak dilakukan delegasi kewenangan (delegation of authority) baik dalam rangka desentralisasi maupun dekonsentrasi. Hal ini menciptakan adanya hubungan kewenangan antara pusat dan daerah dalam menyelenggarakan urusan pemerintahan. Hubungan kewenangan pusat dan daerah bertalian dengan cara pembagian urusan penyelenggaraan pemerintahan. ${ }^{31}$ Pembagian urusan penyelenggaraan pemerintahan berkenaan dengan cara membagi wewenang, tugas, dan tanggung jawab mengatur dan mengurus urusan pemerintahan antara pusat dan daerah.

Pada dasarnya penyelenggaraan pemerintahan di daerah dapat dilakukan melalui tiga cara yakni desentralisasi, dekonsentrasi, dan tugas pembantuan. Ketiga cara tersebut memiliki ciri-ciri sebagaimana tergambar dalam Tabel 1 sebagai berikut:

Tabel 1 Ciri-Ciri Pelaksanaan Asas Penyelenggaraan Pemerintahan Daerah

Berdasarkan Urusan Pemerintahan, Pengaturan, Pengurusan, dan Anggaran ${ }^{32}$

\begin{tabular}{|c|c|c|c|c|c|}
\hline \multicolumn{2}{|c|}{$\begin{array}{l}\text { Asas Penyelenggaraan } \\
\text { Pemerintahan Daerah }\end{array}$} & \multirow{2}{*}{$\frac{\text { Sentralisasi }}{\mathrm{X}}$} & \multirow{2}{*}{$\frac{\text { Dekonsentrasi }}{\mathrm{X}}$} & \multirow{2}{*}{$\begin{array}{c}\begin{array}{c}\text { Tugas } \\
\text { Pembantuan }\end{array} \\
X\end{array}$} & \multirow{2}{*}{$\begin{array}{c}\text { Desentralisasi } \\
-\end{array}$} \\
\hline Urusan & Pemerintah & & & & \\
\hline Pemerintahan & Daerah Otonom & - & - & - & $\mathrm{X}$ \\
\hline \multirow{2}{*}{ Pengaturan } & Pemerintah & $\mathrm{X}$ & $\mathrm{X}$ & $\mathrm{X}$ & - \\
\hline & Daerah Otonom & - & - & $\mathrm{X}$ & $\mathrm{X}$ \\
\hline \multirow{3}{*}{ Pengurusan } & $\begin{array}{l}\text { Aparatur } \\
\text { Pemerintah Pusat }\end{array}$ & $X$ & - & - & - \\
\hline & $\begin{array}{l}\text { Instansi Vertikal/ } \\
\text { Wakil Pemerintah Pusat }\end{array}$ & - & $\mathrm{X}$ & - & - \\
\hline & Aparatur Daerah & - & - & $\mathrm{X}$ & $\mathrm{X}$ \\
\hline \multirow{2}{*}{ Anggaran } & APBN & $\mathrm{X}$ & $\mathrm{X}$ & $\mathrm{X}$ & \\
\hline & APBD & - & - & - & $\mathrm{X}$ \\
\hline
\end{tabular}

Jika dilihat dari segi pengawasan obat di apotek yang dilakukan oleh BPOM, pengawasan obat diselenggarakan dengan asas dekonsentrasi. Ciri-ciri penyelenggaraan

\footnotetext{
${ }^{31}$ Ni’Matul Huda, (2007), Pengawasan Pusat terhadap Daerah dalam Penyelenggaraan Pemerintahan Daerah, cet. 1, Yogyakarta: FH UII Press, hlm. 19.

${ }^{32}$ Bhenyamin Hoessein, (2009), Perubahan Model, Pola, dan Bentuk Pemerintahan Daerah, Jakarta: DIA FISIP UI, hlm. 179 .
} 
pengawasan obat di apotek yang dilakukan oleh BPOM lebih mendekati dengan ciri-ciri asas dekonsentrasi berikut:

a. Pengawasan obat merupakan wewenang Pemerintah Pusat. Ketentuan ini ditegaskan dalam Lampiran UU Pemerintah Daerah yang menyatakan bahwa pengawasan postmarket obat merupakan wewenang Pemerintah Pusat serta Pasal 1 angka (1) Perpres 80 Tahun 2017 yang menyatakan bahwa BPOM adalah lembaga pemerintah nonkementerian yang menyelenggarakan urusan pemerintahan di bidang pengawasan obat.

b. Wewenang pengaturan atau wewenang untuk membuat kebijakan dalam bentuk pengaturan (regeling) merupakan wewenang Pemerintah Pusat. Wewenang BPOM dalam membuat kebijakan yang bersifat pengaturan tercantum dalam Pasal 3 ayat (1) huruf a dan huruf c Perpres 80 Tahun 2017 yang kemudian pengaturan mengenai pengawasan obat di apotek diatur dalam Per BPOM 4 Tahun 2018.

c. Wewenang pengurusan atau wewenang untuk melaksanakan kebijakan merupakan wewenang Pemerintah Pusat. Wewenang BPOM dalam melaksanakan pengawasan obat di apotek diatur dalam Pasal 3 ayat (1) huruf d, huruf e, huruf f, dan huruf g Perpres 80 Tahun 2017. Wewenang BPOM meliputi pelaksanaan pengawasan post-market obat, koordinasi pelaksanaan pengawasan obat dengan instansi Pemerintah Pusat dan Daerah, pemberian bimbingan teknis dan supervisi di bidang pengawasan obat, dan pelaksanaan penindakan terhadap pelanggaran ketentuan peraturan perundang-undangan di bidang pengawasan obat. Dalam hal ini pelaksanaan pengawasan dilakukan oleh BPOM dan Unit Pelaksana Teknis BPOM yang berada di 33 Provinsi dan 40 Kabupaten/Kota. Salah satu bentuk keputusan hasil pengurusan yang bersifat penetapan (beschikking) yang ditetapkan oleh BPOM adalah pemberian sanksi administratif dalam hal terjadinya pelanggaran sebagai tindak lanjut hasil pengawasan. Sanksi administratif dapat berupa peringatan, penghentian sementara kegiatan, dan rekomendasi pencabutan izin.

d. Anggaran yang digunakan dalam rangka pengawasan obat di apotek oleh BPOM berasal dari APBN. 
Dengan demikian, ciri-ciri tersebut dapat digambarkan pada Tabel 2 sebagai berikut:

\section{Tabel 2 Ciri-Ciri Pelaksanaan Asas Penyelenggaraan Pemerintahan Daerah dalam Pengawasan Obat di Apotek oleh BPOM}

\begin{tabular}{|c|c|c|}
\hline $\begin{array}{c}\text { Asas } \\
\text { Penyelenggaraan } \\
\text { Pemerintahan Daerah }\end{array}$ & Ciri Asas Dekonsentrasi & Dekonsentrasi \\
\hline Urusan Pemerintahan & Pusat & Pusat \\
\hline Pengaturan & Pusat & BPOM \\
\hline Pengurusan & $\begin{array}{c}\text { Instansi Vertikal/ } \\
\text { Wakil Pemerintah Pusat }\end{array}$ & $\begin{array}{c}\text { UPT BPOM } \\
\text { (Instansi vertikal BPOM) }\end{array}$ \\
\hline Anggaran & APBN & APBN \\
\hline Simpulan & Dekonsentrasi & $\begin{array}{c}\text { Sesuai dengan } \\
\text { Asas Dekonsentrasi }\end{array}$ \\
\hline
\end{tabular}

Sumber: Peraturan perundang-undangan diolah oleh penulis

Sedangkan, jika dilihat dari segi pengawasan obat di apotek yang dilakukan oleh Pemerintah Daerah, ciri-ciri penyelenggaraannya lebih mendekati dengan ciri-ciri asas tugas pembantuan sebagai berikut:

a. Daerah dilimpahkan wewenang untuk penerbitan izin apotek sebagaimana telah diatur dalam Lampiran UU Pemerintahan Daerah dan Pasal 12 ayat (2) Permenkes 9 Tahun 2017. Pada dasarnya wewenang pemberian izin apotek, berdasarkan Pasal 182 ayat (2) UU Kesehatan secara atributif merupakan wewenang Menteri Kesehatan. Dengan penggunaan kata "dilimpahkan" dalam Pasal 12 ayat (2) Permenkes 9 Tahun 2017 mengandung makna bahwa penerbitan izin apotek merupakan wewenang Pemerintah Pusat. Pemerintah Daerah Kabupaten/Kota hanya melaksanakan penerbitan izin tersebut dan melakukan pengawasan terhadap pelaksanaan perizinan. Tidak ada penyerahan urusan pemerintahan pengawasan apotek kepada Pemerintah Daerah, baik pengawasan terkait dengan pemberian izin dan pengawasan terhadap pelaksanaan perizinan. Dengan demikian, pelimpahan wewenang merupakan dekonsentrasi wewenang atau sebenarrnya kewenangan tetap berada pada Pemerintah Pusat, sedangkan daerah "hanya" menjalankan saja kebijakan-kebijakan yang telah ditetapkan. ${ }^{33}$ Hal ini tercermin dalam peraturan pelaksanaan UU Kesehatan yang selalu menyebutkan bahwa pengawasan dilakukan juga oleh Menteri Kesehatan terhadap segala kegiatan yang berkaitan dengan penyelenggaraan apotek antara lain ketentuan sebagaimana diatur dalam Pasal 46 Permenkes 3 Tahun 2015, Pasal 9 Permenkes 73 Tahun 2016, Pasal 28 Permenkes 9 Tahun 2017.

\footnotetext{
33 Harsanto Nursadi, (2009), "Kewenangan dan Tanggung Jawab Daerah Otonom dalam Perlindungan Lingkungan (Studi Kasus Pengelolaan Bahan Berbahaya Beracun dan Limbah Bahan Berbahaya Beracun di Provinsi DKI Jakarta, Provinsi Jawa Barat, dan Provinsi Jawa Timur)," Disertasi Universitas Indonesia, Jakarta, hlm. 281.
} 
b. Kewenangan yang dilimpahkan kepada daerah adalah kewenangan yang bersifat "mengurus" maka kewenangan "mengatur" yang terkandung dalam norma sebagaimana diatur dalam Pasal 182 ayat (2) UU Kesehatan masih melekat pada Pemerintah Pusat yang dalam hal ini adalah Menteri Kesehatan. Hal ini tercermin dalam Peraturan Daerah di beberapa daerah, seperti DKI Jakarta, Kota Bogor, Kota Depok, Kabupaten Tangerang, dan Kabupaten Bantul, hanya mengatur sebatas kewenangan daerah yakni pengaturan terhadap perizinan apotek. Perkada dari tiga daerah yang mengatur secara langsung mengenai penyelenggaraan apotek lahir atas dasar diskresi karena pembentukan Perkada khusus yang mengatur mengenai penyelenggaraan obat di apotek di daerah tidak diamanatkan dalam Peraturan Menteri Kesehatan atau peraturan perundang-undangan yang lebih tinggi. Dengan demikian, substansi pengaturan yang diatur dalam Perda dan Perkada pada dasarnya tidak mengatur hal baru atau hal khusus yang telah diatur dalam Permenkes.

c. Dalam kerangka wewenang penerbitan izin apotek, UU sektoral mengatur bahwa wewenang penerbitan izin apotek dilekatkan juga dengan wewenang pengawasan terhadap pelaksanaan perizinan di apotek. Dimana pelaksanaan perizinan di apotek meliputi kegiatan pelayanan farmasi klinik dan pengelolaan sediaan farmasi, alat kesehatan, dan bahan medis habis pakai sebagaimana diatur dalam Permenkes 9 Tahun 2017 dan Permenkes 73 Tahun 2016. Dengan demikian aparatur Pemerintah Daerah berwenang menerbitkan izin, melakukan pengawasan terhadap legalitas perizinan apotek, melakukan pengawasan terhadap penyelenggaraan kegiatan apotek yang meliputi pengawasan pelayanan farmasi klinik dan pengawasan pengelolaan sediaan farmasi, alat kesehatan, dan bahan medis habis pakai.

d. Anggaran yang digunakan pemerintah daerah dalam pengawasan obat di apotek berasal dari APBD yang kegiatannya bagian dari program "Perizinan Apotek". Pada umumnya merupakan bagian dari kegiatan pengawasan terhadap perizinan atau pengkajian ulang izin apotek.

Dengan demikian, ciri-ciri tersebut dapat digambarkan pada Tabel 3. Namun, penyelenggaraan pengawasan obat di apotek oleh Pemerintah Daerah menjadi tidak sesuai dengan asas tugas pembantuan. Dari keempat ciri tersebut, terdapat dua ciri pengawasan obat di apotek oleh Pemerintah Daerah yang tidak sesuai dengan ciri asas tugas pembentuan. Pertama, ciri terkait wewenang mengatur. Pada asas tugas pembentuan, selain pusat, daerah juga diberikan wewenang untuk mengatur. Dalam faktanya, pengaturan pengawasan obat di apotek oleh Pemerintah Daerah menggunakan kebijakan 
yang telah ditetapkan di pusat antara lain Permenkes 3 Tahun 2015, Permenkes 73 Tahun 2016, Permenkes 9 Tahun 2017, dan Per BPOM 4 Tahun 2018. Kedua, ciri terkait keuangan atau pembiaayaan tidak sesuai dengan asas tugas pembantuan. Dimana asas tugas pembantuan berciri bahwa wewenang dibiayai oleh APBN. Sedangkan dalam kerangka penerbitan izin apotek yang melekat didalamnya wewenang pengawasan terhadap izin apotek, kegiatan pengawasan dibiayai oleh APBD.

\section{Tabel 3 Ciri-Ciri Pelaksanaan Asas Penyelenggaraan Pemerintahan Daerah dalam} Pengawasan Obat di Apotek oleh Pemda Kabupaten/Kota

\begin{tabular}{|c|c|c|}
\hline $\begin{array}{c}\text { Asas } \\
\text { Penyelenggaraan } \\
\text { Pemerintahan Daerah }\end{array}$ & $\begin{array}{c}\text { Ciri Asas } \\
\text { Tugas Pembantuan }\end{array}$ & Tugas Pembantuan \\
\hline Urusan Pemerintahan & Pusat & Pusat \\
\hline Pengaturan & Pusat dan Daerah & $\begin{array}{c}\text { Pusat (Permenkes } \\
\text { dan BPOM) }\end{array}$ \\
\hline Pengurusan & Aparatur Pemerintah Daerah & Aparatur Pemerintah Daerah \\
\hline Anggaran & APBN & APBD \\
\hline Simpulan & Tugas Pembantuan & $\begin{array}{c}\text { Mendekati Ciri } \\
\text { Tugas Pembantuan }\end{array}$ \\
\hline
\end{tabular}

Sumber: Peraturan perundang-undangan diolah oleh penulis

Jika ditinjau dari asas penyelenggaraan pemerintahan daerah, pengawasan obat di apotek seharusnya diselenggarakan dengan asas dekonsentrasi. Dimana wewenang pengawasan terhadap pengelolaan obat di apotek yang diatur dalam Permenkes 73 Tahun 2016 dan Permenkes 9 Tahun 2017 hanya dilekatkan kepada BPOM. Sedangkan, Pemerintah Daerah dilekatkan wewenang pengawasan yang tidak menjadi wewenang Pemerintah Pusat dalam hal ini BPOM. Wewenang pengawasan tersebut dapat meliputi wewenang pengawasan terhadap administrasi perizinan, persyaratan teknis perizinan, dan penyelenggaraan pelayanan farmasi klinik oleh apotek. Jika pengawasan pengelolaan obat di apotek dilakukan oleh dua lembaga maka berpotensi menghambat efektivitas pengawasan obat. Misalnya satu apotek dilakukan pemeriksaan dua kali oleh BPOM dan oleh Dinas Kesehatan. Selain itu, hal ini dapat berpotensi adanya dualisme dalam pengambilan kebijakan terhadap tindak lanjut hasil pengawasan yang berakibat tidak terjaminnya kepastian hukum bagi masyarakat, khususnya pemilik sarana apotek yang dilakukan pemeriksaan. 


\section{Upaya Mewujudkan Efektivitas Pengawasan Obat di Apotek}

Pengawasan, menurut Prajudi Atmosudirdjo, adalah "proses kegiatan-kegiatan yang membandingkan apa yang dijalankan, dilaksanakan, atau diselenggarakan dengan apa yang dikehendaki, direncanakan, atau diperintahkan. Sistem pengawasan yang efektif adalah sarana terbaik untuk membuat segala sesuatunya berjalan dengan baik dalam administrasi negara." 34 Sedangkan menurut Sondang P. Siagian, pengawasan adalah "proses pengamatan pelaksanaan seluruh kegiatan organisasi untuk menjamin agar semua pekerjaan yang sedang dilaksanakan berjalan sesuai dengan rencana yang telah ditentukan."35

Kewenangan pengawasan diatur berdasarkan peraturan perundang-undangan. Sebagai negara hukum, pengawas hanya memiliki kewenangan melakukan pengawasan terhadap warga negara sejauh kewenangan itu mengalir dari undang-undang. Menurut Indroharto, penerapan asas legalitas akan menunjang berlakunya kesamaan perlakuan dan kepastian hukum. Kesamaan perlakuan terjadi karena setiap orang yang berada dalam situasi seperti yang ditentukan dalam ketentuan undang-undang itu berhak dan berkewajiban untuk berbuat seperti apa yang ditentukan dalam undang-undang tersebut. Sedangkan kepastian hukum akan terjadi karena suatu peraturan dapat membuat semua tindakan yang akan dilakukan pemerintah itu dapat diramalkan atau diperkirakan lebih dahulu, dengan melihat kepada peraturan-peraturan yang berlaku, maka pada asasnya dapat dilihat atau diharapkan apa yang akan dilakukan oleh aparat pemerintahan yang bersangkutan. Dengan demikian, warga masyarakat dapat menyesuaikan dengan keadaan tersebut. ${ }^{36}$ Selain itu, menurut H.D. Stout mengungkapkan "het legaliteitsbeginsel beoogt de rechtspositie van de burger jegens de overheid te waarborgen yang artinya asas legalitas dimaksudkan untuk memberikan jaminan kedudukan hukum warga negara terhadap pemerintah." 37

Pengawasan merupakan syarat bagi dimungkinkannya pengenaan sanksi. Pelaksanaan dari pengawasan mendukung penegakan hukum (handhaving). Warga negara melihat bahwa penguasa dengan sungguh-sunggguh menegakan peraturan perundang-

\footnotetext{
${ }^{34}$ S. Prajudi Atmosudirdjo, Hukum Administrasi Negara, hlm. 84.

${ }^{35}$ Sondang P. Siagian, (1970), Filsafat Administrasi, Jakarta: Gunung Agung, hlm. 107.

${ }^{36}$ Indroharto, (1993), Usaha Memahami Undang-Undang tentang Peradilan Tata Usaha Negara: Buku I, Jakarta: Pustaka Sinar Harapan, hlm. 83 - 84.

${ }^{37}$ H.D. Stout, De Betekenissen, dalam HR, Hukum Administrasi Negara, hlm. 95.
} 
undangan. ${ }^{38}$ Sanksi mengambil peran penting dalam proses penegakan hukum. Sebagaimana dikemukakan oleh Philipus M. Hadjon, "sanksi merupakan bagian penutup yang penting di dalam hukum karena tidak ada gunanya memasukkan kewajiban atau larangan bagi para warga di dalam peraturan perundang-undangan, manakala aturan-aturan tingkah laku itu tidak dapat dipaksakan." ${ }^{39}$ Salah satu bentuk sanksi adalah sanksi administratif. Menurut Prajudi Atmosudirdjo,

Pengadaan sanksi oleh pemerintah dilakukan bilamana dalam suatu tindak hukum administrasi terdapat suatu ikatan-hukum (rechtsbetrekking) di antara administrasi dan seorang warga masyarakat. Warga masyarakat terikat (mempunyai verplichting) untuk melakukan atau memenuhi sesuatu, sedangkan dia lalai atau tidak dapat menunaikannya, maka administrasi dapat melakukan sanksi hukum administrasi negara terhadapnya tanpa perantaraan atau melalui hakim pengadilan negeri. ${ }^{40}$

Dalam hukum administrasi negara, penggunaan sanksi administrasi merupakan kewenangan pemerintahan. Kewenangan ini berasal dari aturan hukum administrasi negara tertulis dan tidak tertulis. Pada umumnya memberikan kewenangan kepada pemerintah untuk menetapkan norma-norma hukum administrasi negara tertentu, diiringi pula dengan memberikan kewenangan untuk menegakkan norma-normra itu melalui penerapan sanksi bagi merreka yang melanggar norma-norma hukum administrasi negara tersebut. Dengan kata lain, sanksi sebagai tindakan pemerintah harus memenuhi asas legalitas bahwa segala sesuatunya yang dilakukan atau diputuskan wajib berdasasrkan suatu ketentuan undangundang serta pejabat administrasi negara dalam bertindak (menjalankan tugas-tugasnya) harus dilandasi wewenang yang sah, yang diberikan peraturan perundang-undangan. Asas legalitas merupakan syarat utama bagi pejabat pemerintah yang melakukan pengawasan dalam rangka penegakan hukum.

Hubungan kewenangan pusat dan daerah dalam pengawasan obat di apotek merupakan tantangan dalam efektivitas pengawasan obat di Indonesia. Pengawasan obat di apotek yang memberikan legalitas bagi Pemerintah Pusat, Pemerintah Daerah Provinsi, dan Pemerintah Kabupaten/Kota menimbulkan adanya irisan kewenangan dalam pengawasan obat. Hal ini dapat berakibat terabaikannya kesamaan perlakuan dan kepastian hukum bagi masyarakat. Masing-masing lembaga dapat memiliki pandangan yang berbeda dalam memandang persoalan pengawasan obat di apotek, sehingga mempengaruhi kebijakan yang diambil. Kebijakan tersebut dapat saling bertentangan dan membingungkan

\footnotetext{
${ }^{38}$ Philipus M. Hadjon, et al, (2002), Pengantar Hukum Administrasi Indonesia (Introduction to the Indonesian Administrative Law), Yogyakarta: Gadjah Mada University Press, hlm. 248.

${ }^{39}$ Ibid., hlm. 245.

${ }^{40}$ S. Prajudi Atmosudirdjo, Hukum Administrasi Negara, hlm. 141.
} 
masyarakat. Sebagai ilustrasi, BPOM dan Dinas Kesehatan dapat mengenakan sanksi yang berbeda sebagai tindak lanjut pengawasan yang dilakukan oleh masing-masing instansi karena masing-masing lembaga memiliki kebijakannya sendiri dalam menetapkan pola tindak lanjut hasil pengawasan. Jika dilihat pada dasarnya bahwa pengawasan obat di apotek adalah pengawasan terhadap produk/obat maka seharusnya kewenangan pengawasan adalah kewenangan Pemerintah Pusat. Lembaga Pemerintah Pusat yang ditugasi untuk melaksanakan pengawasan obat adalah BPOM berdasarkan Perpres 80 Tahun 2017.

Dalam rangka efektivitas pengawasan, perlu dilakukan berbagai upaya untuk menegaskan wewenang Pemerintah Pusat dan Pemerintah Daerah melalui harmonisasi legislasi dan regulasi. ${ }^{41}$ Pertama, perlunya melakukan revisi terhadap Permenkes 73 Tahun 2016 dan Permenkes 9 Tahun 2017. Kedua Permenkes ini memberikan kewenangan kepada Pemerintah Daerah untuk melakukan pengawasan terhadap pengelolaan obat. Padahal pengawasan terhadap pengelolaan obat telah diatur bahwa pengawasan tersebut diselenggarakan secara dekonsentrasi. Pengaturan mengenai pengawasan dari kedua Permenkes ini perlu direvisi. Dengan menegaskan bahwa wewenang pengawasan obat/pengawasan pengelolaan obat di apotek merupakan kewenangan Pemerintah Pusat, dalam hal ini adalah BPOM. Sedangkan, Pemerintah Daerah berwenang melakukan pengawasan terhadap administrasi perizinan, persyaratan teknis perizinan, dan pengawasan terhadap pelayanan farmasi klinik (salah satu bentuk penyelenggaraan kegiatan di apotek yang tidak beririsan dengan kewenangan BPOM).

Kedua, perlunya disusun undang-undang khusus yang secara komprehensif mengatur mengenai pengawasan obat. Substansi yang diatur dalam undang-undang lex specialis tersebut mengatur secara tegas batas wewenang dari pihak-pihak yang terlibat dalam pengawasan obat. $^{42}$ Melalui undang-undang khusus ini disinkronisasikan pembagian

\footnotetext{
${ }^{41}$ Harmonisasi legislasi dan regulasi adalah salah satu kegiatan mensinkronisasi peraturan perundang-undangan agar tidak bertentangan dengan Pancasila, UUD NRI Tahun 1945, peraturan perundang-undangan yang lebih tinggi, dan putusan pengadilan.

42 Indonesia, Dewan Perwakilan Rakyat, Keputusan DPR tentang Program Legislasi Nasional Rancangan Undang-Undang Prioritas Tahun 2016 dan Perubahan Program Legislasi Nasional Rancangan UndangUndang 2015 - 2019, Keputusan DPR Nomor 4/DPR RI/III/2015-2016. Pengaturan khusus dan komprehensif tentang pengawasan obat dan makanan sangat diperlukan untuk memberikan perlindungan yang lebih baik terhadap kesehatan masyarakat dari risiko obat dan makanan yang tidak memenuhi persyaratan keamanan, khasiat/manfaat, dan mutu. Berdasarkan Keputusan Dewan Perwakilan Rakyat Nomor 4/DPR RI/III/2015-2016 tentang Program Legislasi Nasional Rancangan Undang-Undang Prioritas Tahun 2016 dan Perubahan Program Legislasi Nasional Rancangan Undang-Undang 2015 - 2019, DPR RI telah menetapkan dua Rancangan Undang-Undang terkait pengawasan obat dan makanan, yaitu: (1) RUU tentang Pembinaan, Pengembangan, dan Pengawasan Sediaan Farmasi, Alkes, dan PKRT sebagai usulan DPR dan DPD (list Nomor 115 usulan Komisi IX, Fraksi PKS, Fraksi PAN, DPD Komite II, dan Komisi Hukum Nasional); dan (2) RUU tentang Pengawasan
} 
wewenang antara Pemerintah Pusat dan Pemerintah Daerah dalam pengawasan obat di apotek sebagaimana telah diatur dalam UU Pemerintahan Daerah. Kewenangan penerbitan izin apotek yang telah dilimpahkan Pemerintah Daerah Kabupaten/Kota seharusnya juga tertuang secara atributif dalam UU sektoral, sehingga diharapkan dengan adanya undangundang khusus ini mengatur secara tegas pembagian wewenang antara Pemerintah Pusat dan Pemerintah Daerah dan ruang lingkup wewenangnya.

Ketiga, perkuatan legalitas formal kelembagaan pengawas obat dalam hal ini BPOM sebagai pusat koordinasi pengawasan obat. Kedudukan suatu lembaga dipengaruhi oleh norma sumber kewenangan lembaga tersebut. Menurut Prajudi Atmosudirdjo, kewenangan atau kekuasaan formal adalah kekuasaan terhadap segolongan orang tertentu atau kekuasaan terhadap suatu bidang pemerintahan yang berlandaskan peraturan perundangundangan agar tidak timbul kesewenang-wenangan. ${ }^{43}$ Sebagaimana telah dijelaskan sebelumnya bahwa penunjukan BPOM sebagai koordinator dalam pelaksanaan pengawasan obat telah diatur dalam beberapa instrumen hukum antara lain Peraturan Presiden Nomor 80 Tahun 2017 tentang Badan Pengawas Obat dan Makanan; Instruksi Presiden Nomor 3 Tahun 2017 tentang Peningkatan Efektivitas Pengawasan Obat dan Makanan; dan Peraturan Menteri Dalam Negeri Nomor 41 Tahun 2018 tentang Peningkatan Koordinasi Pembinaan dan Pengawasan Obat dan Makanan di Daerah. Namun, sumber kewenangan BPOM sebagai pusat koordinasi murni dari Presiden sebagai kepala pemerintahan, keberadaannya secara hukum hanya didasarkan atas kebijakan Presiden atau beleid Presiden (presidential policy). Perkuatan kedudukan dan kewenangan BPOM dalam pengawasan obat perlu diatur dalam suatu undang-undang. Dalam undangundang tersebut seharusnya dinyatakan secara tegas pembentukan BPOM sebagai lembaga pengawas obat, memberikan kewenangan kepada BPOM untuk melaksanakan pengawasan obat secara atributif, serta memberikan kewenangan kepada BPOM sebagai pusat koordinasi pengawasan obat. Sebagaimana dikemukakan Jimly Asshiddiqie bahwa:

Lembaga yang dibentuk berdasarkan undang-undang berarti sumber kewenangannya berasal dari pembentuk undang-undang. Proses pemberian kewenangan kepada lembaga yang dibentuk dengan undang-undang melibatkan peran DPR dan Presiden. Oleh karena itu, pembubaran, pengubahan bentuk dan kewenangan lembaga ini juga memerlukan keterlibatan DPR dan Presiden. Lembaga ini tidak dapat diubah bentuk

Obat dan Makanan dan Pemanfaatan Obat Asli Indonesia sebagai usulan DPR (list Nomor 121 usulan Komisi IX dan Fraksi PKS).

${ }^{43}$ S. Prajudi Atmosudirdjo, Hukum Administrasi Negara, hlm. 78. 
dan kewenangan atau dibubarkan kecuali dengan mengubah atau mencabut undangundangnya. $^{44}$

Dengan diaturnya BPOM dalam suatu undang-undang maka secara kelembagaan BPOM memiliki kedudukan dan kewenangan yang lebih kuat dalam mengawal efektivitas pengawasan obat di Indonesia dengan tujuan utama untuk menjamin keamanan, khasiat, dan mutu obat. Hal senada juga disampaikan oleh WHO dalam Effective Drug Regulation yang mengemukakan bahwa salah satu elemen penting untuk memastikan regulasi di bidang obat yang efektif adalah "Comprehensive medicine legislation. Legislation should provide a basic legal framework and be flexible enough to provide adequate powers to the National Regulatory Authority (NRA). The legislation ensures legal provision for the creation of an NRA. "45

\section{Penutup}

Berdasarkan hasil penelitian yang telah diuraikan sebelumnya, penulis mengambil simpulan bahwa pola pembagian kewenangan dalam pengawasan obat di apotek antara Pemerintah Pusat dengan Pemerintah Daerah berdasarkan UU Pemerintahan Daerah yakni: a) urusan pemerintahan yang menjadi kewenangan Pemerintah Pusat adalah pengawasan postmarket obat; dan b) urusan pemerintahan yang menjadi kewenangan Pemerintah Daerah Kabupaten/Kota adalah penerbitan izin apotek. Namun, pengaturan dalam Permenkes 73 Tahun 2016 dan Permenkes 9 Tahun 2017, memberikan kewenangan juga kepada Pemerintah Daerah untuk melakukan pengawasan obat di apotek. Pengawasan obat di apotek seharusnya diselenggarakan dengan asas dekonsentrasi. Dimana wewenang pengawasan terhadap pengelolaan obat di apotek yang diatur dalam Permenkes 73 Tahun 2016 dan Permenkes 9 Tahun 2017 hanya dilekatkan kepada BPOM. Sedangkan, Pemerintah Daerah dilekatkan wewenang pengawasan yang tidak menjadi wewenang Pemerintah Pusat dalam hal ini BPOM. Jika pengawasan pengelolaan obat di apotek dilakukan oleh dua instansi maka berpotensi menghambat efektivitas pengawasan obat dan berpotensi tidak memberikan jaminan kepastian hukum bagi masyarakat. Saran yang dapat diberikan yaitu perlunya disusun undang-undang khusus yang secara komprehensif mengatur mengenai pengawasan obat, serta perkuatan legalitas formal kelembagaan pengawas obat dalam hal ini BPOM sebagai pusat koordinasi pengawasan obat menjadi diatur dalam suatu undang-undang.

\footnotetext{
${ }^{44}$ Jimly Asshiddiqie, (2006), Perkembangan dan Konsolidasi Lembaga Negara Pasca Reformasi, cet. 2, Jakarta: Konstitusi Press, hlm. 51.

${ }^{45}$ World Health Organization, "Effective Medicines Regulation: Ensuring Safety, Efficacy, and Quality - WHO Perspectives on Medicines," http://apps.who.int/medicinedocs/en/d/Js4921e/4 .html, diakses pada tanggal 9 Oktober 2019.
} 


\section{Daftar Pustaka}

\section{Buku:}

Asshiddiqie, Jimly. (2006). Perkembangan dan Konsolidasi Lembaga Negara Pasca Reformasi. Cet. 2. Jakarta: Konstitusi Press.

Atmosudirdjo, S. Prajudi. (1994). Hukum Administrasi Negara. Cet. 10. Jakarta: Ghalia Indonesia.

Azhary. (1995). Negara Hukum Indonesia. Jakarta: UI Press.

Hadjon, Philipus M. et al. (2002). Pengantar Hukum Administrasi Indonesia (Introduction to the Indonesian Administrative Law). Yogyakarta: Gadjah Mada University Press.

Hoessein, Bhenyamin. (2009). Perubahan Model, Pola, dan Bentuk Pemerintahan Daerah. Jakarta: DIA FISIP UI.

HR, Ridwan. (2011). Hukum Administrasi Negara. Jakarta: Rajawali Pers.

Huda, Ni'Matul. (2007). Pengawasan Pusat terhadap Daerah dalam Penyelenggaraan Pemerintahan Daerah. Cet. 1. Yogyakarta: FH UII Press.

Indroharto. (1993). Usaha Memahami Undang-Undang tentang Peradilan Tata Usaha Negara: Buku I. Jakarta: Pustaka Sinar Harapan.

Leyland, Peter and Terry Woods. (1999). Administrative Law. London: Blackstone Press Limited.

Nugraha, Safri. et al. (2005). Hukum Administrasi Negara. Cet. 1. Jakarta: Badan Penerbit Fakultas Hukum Universitas Indonesia.

Siagian, Sondang P. (1970). Filsafat Administrasi. Jakarta: Gunung Agung.

Situmorang, Victor. (1988). Dasar-Dasar Hukum Administrasi Negara. Jakarta: Bina Aksara.

Soekanto, Soerjono dan Sri Mamudji. (2010). Penelitian Hukum Normatif: Suatu Tinjauan Singkat. Jakarta: Rajawali Press.

Utrecht, E. (1957). Pengantar dalam Hukum Indonesia. Jakarta: Ichtiar.

\section{Disertasi:}

Nursadi, Harsanto. (2009). "Kewenangan dan Tanggung Jawab Daerah Otonom dalam Perlindungan Lingkungan (Studi Kasus Pengelolaan Bahan Berbahaya Beracun dan Limbah Bahan Berbahaya Beracun di Provinsi DKI Jakarta, Provinsi Jawa Barat, dan Provinsi Jawa Timur).” Disertasi Universitas Indonesia, Jakarta.

\section{Peraturan Perundang-undangan:}

Indonesia. Undang-Undang Dasar Negara Republik Indonesia Tahun 1945.

. Undang-Undang tentang Psikotropika. UU No. 5 Tahun 1997. LN No. 10 Tahun 1997. TLN No. 3671. 
.Undang-Undang tentang Narkotika. UU No. 35 Tahun 2009. LN No. 143 Tahun 2009. TLN No. 5062.

. Undang-Undang tentang Kesehatan. UU No. 36 Tahun 2009. LN No. 144 Tahun 2009. TLN No. 5063.

. Undang-Undang Pemerintahan Daerah. UU No. 23 Tahun 2014. LN No. 244 Tahun 2014. TLN No. 5587.

. Peraturan Presiden tentang Badan Pengawas Obat dan Makanan. Perpres No. 80 Tahun 2017. LN No. 180 Tahun 2017.

Indonesia, Menteri Kesehatan. Peraturan Menteri Kesehatan tentang Standar Pelayanan Kefarmasian di Apotek. Permenkes No. 73 Tahun 2016, BN No. 50 Tahun 2017.

. Peraturan Menteri Kesehatan tentang Apotek. Permenkes No. 9 Tahun 2017. BN No. 276 Tahun 2017.

Indonesia, Dewan Perwakilan Rakyat. Keputusan DPR tentang Program Legislasi Nasional Rancangan Undang-Undang Prioritas Tahun 2016 dan Perubahan Program Legislasi Nasional Rancangan Undang-Undang 2015 - 2019. Keputusan DPR Nomor 4/DPR RI/III/2015-2016.

\section{Internet:}

World Health Organization. "Effective Medicines Regulation: Ensuring Safety, Efficacy, and Quality - WHO Perspectives on Medicines," http://apps.who.int/medicinedocs/en/d/ Js4921e/4.html. Diakses pada tanggal 9 Oktober 2019. 